\title{
CORPORATE INSOLVENCY IN EUROPE
}

\section{MAŁGORZATA PORADA-ROCHOŃ}

University of Szczecin, Faculty of Management and Economics of Services, POLAND

e-mail: malgorzata.rochon@wp.pl

RECEIVED
ACCEPTED
JEL
CLASSIFICATION

KEYWORDS

ABSTRACT
4 December 2017

5 January 2018

G32

insolvency, company, finance

Introduction: The insolvency of enterprises is considered both from a macro and microeconomic viewpoint. Enterprises identify insolvency in the period of the largest economic boom and more often in the periods of economic instability and crises or recession, due to the increasing risk of its occurrence. In addition, the importance of insolvency is crucial from the viewpoint of the potential effects of economic bankruptcy and bankruptcy from a legal viewpoint.

Research Objective/Hypothesis: The aim of this paper is to analyze selected aspects of the corporate insolvency in Europe. The first objective is, to determine whether the cost and time of the insolvency proceeding are shorter in OECD countries when compared to others in Europe. The second objective is to identify Poland's position according to the aspect of insolvency, in the context of the countries surveyed. Hypothesis: There is relationship between high income in OECD countries and recovery rate.

Research methodology: The data comes from the Doing Business 2018 report. It was used Spearman correlation.

Findings: There is a need for continuous improvement of legal systems to facilitate resolving insolvencies. There is moderate correlation (Spearman) at approx. 0.69 between high income in OECD countries and recovery rate. It is statistically significant correlation ( $p$-value $<0.05)$.

There are two weak negative (downhill relationships) correlations (Spearman) between high income in OECD countries and time (first relationship) or cost (second relationship).

\section{Introduction}

The subject of insolvency is widely described in the literature of the subject, both from the theory viewpoint and economic practice. Apart from financial disruptions and bankruptcies of enterprises, considerations in the theory of economics (the object of which is insolvency), are rich achievements in the literature of the subject. The insolvency of enterprises is considered both from a macro and microeconomic viewpoint. Enterprises identify insolvency in the 
period of the largest economic boom and more often in the periods of economic instability and crises or recession, due to the increasing risk of its occurrence. In addition, the importance of insolvency is crucial from the viewpoint of the potential effects of economic bankruptcy and bankruptcy from a legal viewpoint.

The scope of defining insolvency is wide and there are inconsistencies in the scope of application as well as the understanding of this concept, but also in the scope of measuring insolvency. One of the reasons for this is the dichotomous approach to insolvency, i.e. economic and legal.

Many factors which are difficult to predict exist in the modern economy, so it is not easy and often impossible to identify and counteract them. Insolvency should be treated more broadly than just as a loss of ability to pay liabilities. Insolvency issues should be treated as a whole, taking into account liquidity problems, capital structure, as well as searching for external factors that often surprise entrepreneurs (Franc-Dabrowska, Porada-Rochoń, 2014, p. 12).

Considerations of economic theory, the subject of which is the issue of insolvency, are relatively modest achievements in the literature of the subject. Such state is caused by, among others, multiplicity and diversity of approaches to the definition of insolvency, lack of coherence in the methodology of its diagnosis and ways of counteracting their effects and minimizing them. The lack of coherence also applies to the identification of tools that effectively and relatively easily identify the growing risk of insolvency.

The aim of this paper is to analyze selected aspects of the corporate insolvency in Europe.

The first objective is, to determine whether the cost and time of the insolvency proceeding are shorter in OECD countries when compared to others in Europe. The second objective is to identify Poland's position according to the aspect of insolvency, in the context of the countries surveyed.

The paper is structured as follows: Section 2 Theoretical review, Section 3 explores the method followed, describes data sources and outlines how to measure the variables used in the analysis, presents hypothesis; Sections 4 presents and discuss the results obtained and Section 5 presents the main conclusions.

\section{Litepature review}

It is generally assumed that insolvency is an economic and financial situation of an enterprise that prevents it from covering liabilities to creditors There may be many reasons for the insolvency of enterprises (Leksykon..., 1991, p. 49) The lack of possibility to repay liabilities with owned assets indicates Łodziana (2003, p. 25).

One of the key reasons is delay in payment transactions, which in some cases results in payment delays. As Dankiewicz points out, failure to settle receivables on time is not so much a consequence of actual payment bottlenecks on the borrowers' side, how many attempts they have made to replace a working loan with a trade credit in financing current operations (Dankiewicz, 2009, p. 70) An important determinant of insolvency is excessive debt. Another reason for insolvency is level of short term debt. A lack of short term debt can lead to solvency problem.

What is more, the issue of level of cash is highlighted. Excess cash improves trading continuity and liquidity risk. It also adds to the stream of studies on the link between corporate liquidity management and the expected equity returns and that excess cash is an important determinant of the liquidity beta (Huang, Mazouz, 2018, p. 289).

Insolvency can threaten not only the enterprise that is struggling with payment difficulties, but also entities that accumulate excessive cash levels, incurring alternative costs of their passive maintenance, as well as limiting (or even preventing) their development. On the other hand, the risk of insolvency applies to enterprises in which 
you do not invest, as well as those that have been reinvested (Franc-Dąbrowska, Porada-Rochoń, Zioło, Babczuk, 2015, p. 20).

According to the result of research of Diamond and Verrecchia using disclosure to reduce information asymmetry can lead to lower cost of capital by increasing liquidity for a firm's securities (Diamond, Verrecchia, 1991, pp. 1325-1359).

Recently, the issue of payment discipline and payment morality has been also highlighted, which results in a domino effect or the contingency effect causing a chain of insolvency (Mączyńska, 2017, p. 9-10).

According to the surveys of Franc-Dąbrowska and Porada-Rochon (2014), insolvency should be treated broadly, not only as perceiving it as a loss of ability to pay liabilities. The problem of insolvency should be considered as a whole, with the simultaneous examination of liquidity, capital structure (equity resources) and the external factors should be considered as well. It is difficult to quantify them unequivocally, as these are variables often unexpected for entrepreneurs, and have their source in globalization processes and turbulent environment (Franc-Dąbrowska, Porada-Rochoń, 2014, p. 265).

According to the Euler Hermes Report, in the year 2017, 900 companies in Poland were declared insolvent, by $12 \%$ more than in 2016 . The reason for insolvency is prolonged payment dates and lack of financial security due to low margins. The main problems of entrepreneurs are prolonging payment terms and increasing payment delays.

The consequence of insolvency of enterprises may be bankruptcy in the economic sense or bankruptcy in the legal sense. The rest of the article will be devoted to the solutions and results of the insolvency in the legal sense.

The major precedent for getting into insolvency process/procedure/operation in the countries like Romania, Bulgaria, Poland, Hungry, Czech Republic and Slovakia is deficiency of liquidity and the lack of ability of a company to pay its present debts. In the case of Hungary this norm is the only one which causes the start of proceedings. In the case of Bulgaria, Czech Republic, Poland and Slovakia indebtedness brought in as a benchmark for opening insolvency operations/procedures. That is to say, those emerging countries of Eastern Europe followed the German model. Yet, the motivation of this criterion is difficult, given the differences between market value and book value of assets (Dăianu, Pîslaru, Voinea, 2004, pp. 37-58 in Georgescua, Baciub, 2014, p. 785). The country which does not apply those criterions in order to start the insolvency proceedings is Romania. Czech Republic or Romania gave the debtor the opportunity to rearrange because of introducing an imminent insolvency criterion. The aim of introducing this criterion was to encourage reorganizations, in the detriment of liquidations (Georgescua, Baciub, 2014, p. 785).

There are separate laws in Poland existing from 1st January 2016. These acts cover insolvencies and the restructuring of companies experiencing payment problems. The reason of introducing these regulations was willingness to encourage the greater use of restructuring procedures - especially as recovery tools for companies faced with temporary liquidity problems.

\section{Research Methods}

The aim is to analyze selected aspects of corporate insolvency in Europe.

Hypothesis: There is relationship between high income in OECD countries and recovery rate.

The data comes from the Doing Business 2018 report and includes the following variables:

1. DTF score for resolving insolvency $(0-100)$ covers recovery rate and strength of insolvency framework.

2. Time to resolve insolvency (years) represents the average time to close a business. 
3. Cost (\% of debtor's estate) represents the average cost of bankruptcy proceedings. The cost of the proceedings is recorded as a percentage of the estate's value. Measured as percentage of estate value: Court fees, Fees of insolvency administration, Lawyers' fees, Assessors' and auctioneers' fees, other related fees.

4. Recovery rate (cents on the dollar): it calculates how many cents on the dollar claimants (creditors, tax authorities, and employees) recover from an insolvent firm. The recovery rate is calculated based on the time, cost and outcome of insolvency proceedings in each economy. To make the data on the time, cost and outcome of insolvency proceedings comparable across economies, several assumptions about the business and the case are used.

5. Strength of insolvency framework index $(0-16)$ measures the quality of insolvency laws that govern relations between debtors, creditors and the court. The strength of the insolvency framework index is based on four other indices: commencement of proceedings index, management of debtor's assets index, reorganization proceedings index and creditor participation index.

It was used Spearman correlation.

\section{Results}

By analyzing the DTF score for resolving insolvency (Figure 1) responsible for the overall assessment of the effectiveness of procedures, the highest result applies to countries: Finland 92.82, Germany 90.27 Norway 85.94, representants of OECD High income countries Interestingly, from 2011 none of these countries have any changes in the law. Nevertheless, according to the Euler Hermes Report, Finland is characterized by the following issues: The payment behavior of domestic companies is excellent with payments taking place in 25 days on average, and the EU framework provides reliable tools when it comes to late payment; Legal action for undisputed debt is usually resolved quickly (between 3 to 6 months), however, when the debtor's assets are difficult to locate, or the debt is disputed, it can become time consuming. Although, the insolvency law aims at rescuing companies facing financial difficulties to increase repayment possibilities, most reconstruction procedures spread over years (or fail) thus leaving the creditors with no or very few dividends, while liquidation procedures leave very low recovery chances to unsecured creditors (Doing Business..., 2017).

Sweden and Germany can really serve as models, being countries with the lowest complexity of local payment practices, local court proceedings and local bankruptcy proceedings (Euler Hermes, 2018).

Out of the 41 countries, Poland took 27 th place with a score of 77,71 , with an average of 68 . This is a good result, however in subsequent years it should improve due to changes that have been reported in 2017 in the field of law (Figure1).

The weakest result was recorded by: Ukraine 28.24; Malta 38.07. In the 2014, Ukraine made resolving insolvency easier by strengthening the rights of secured creditors, introducing new rehabilitation procedures and mechanism. It made invalidating suspect transactions easier and shortening the statutory periods for several steps of the insolvency process.

With reference to Recovery rate, the highest score was recorded in the case of Norway 93.1; Netherlands 89.7; Slovenia 88.7. Poland recorded 63.1 with an average of 57.83. The lowest level of this meter is assigned: Ukraine 8.9 . 


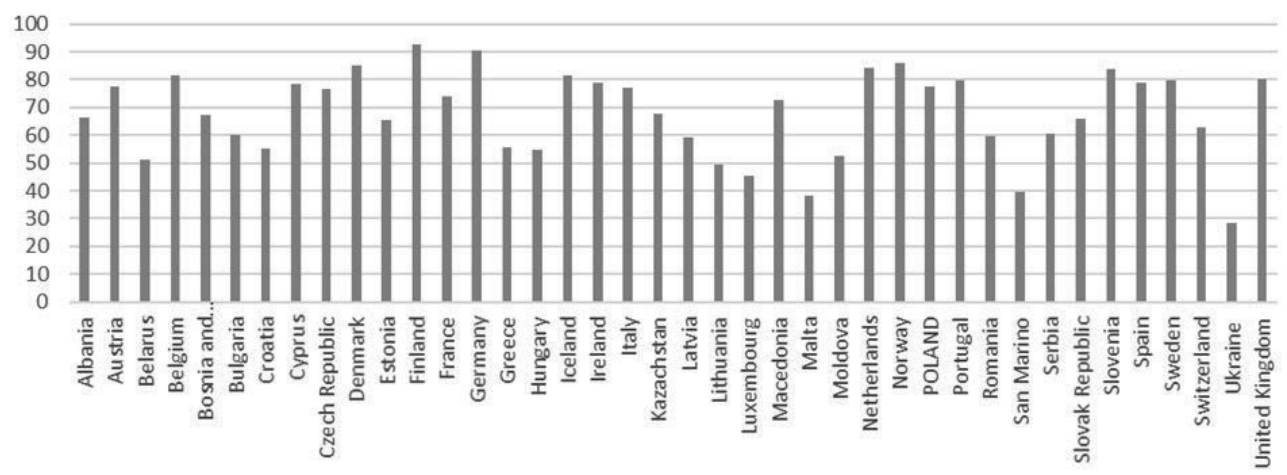

Figure 1. Dtf score for resolving insolvency, 2018

Source: own elaboration on the basis of Doing Business... (2017).

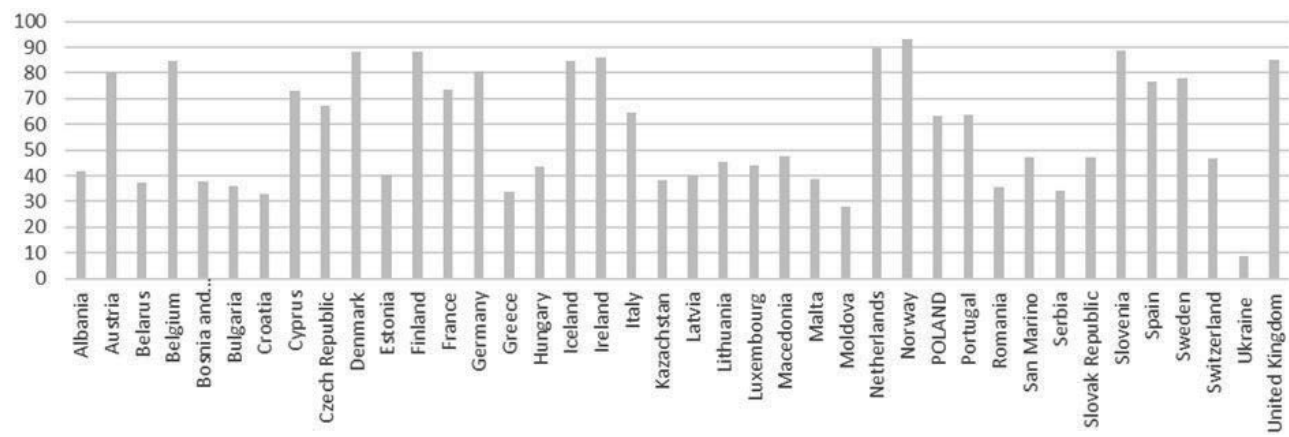

Figure 2. Recovery rate in European countries (cents on the dollar)

Source: own elaboration on the basis of Doing Business... (2017).

There is moderate correlation (Spearman) at approx. 0.69 between high income in OECD countries and recovery rate. It is statistically significant correlation ( $p$-value $<0.05$ ). There is downhill relationship between time and recovery rate at approx. 0.76 - high negative correlation (Spearman and statistically significant). At the same time was moderate negative (downhill) relationship between cost and recovery rate: cost increased and recovery rate decreased, or conversely.

The high level of this measure is probably caused by the early detection of irregularities in the financial condition and the implementation of liquidation procedures. A higher level of the recovery rate can be related to a large commitment and cooperation with stakeholders, as well as owning early warning systems. McGowan with team (2017) indicate, among others, two important issues: lack of prevention and streamlining (include: the lack of early warning mechanisms, preinsolvency regimes and special insolvency procedures for small and medium-sized enterprises), as well as barriers to restructuring (include: creditors' inability to initiate restructuring, an indefinite stay 
on assets, lack of priority given to new financing, no cram-down of restructuring plans on dissenting creditors and the dismissal of incumbent management during restructuring (McGowan, Andrews, Millot, 2017, p. 9).

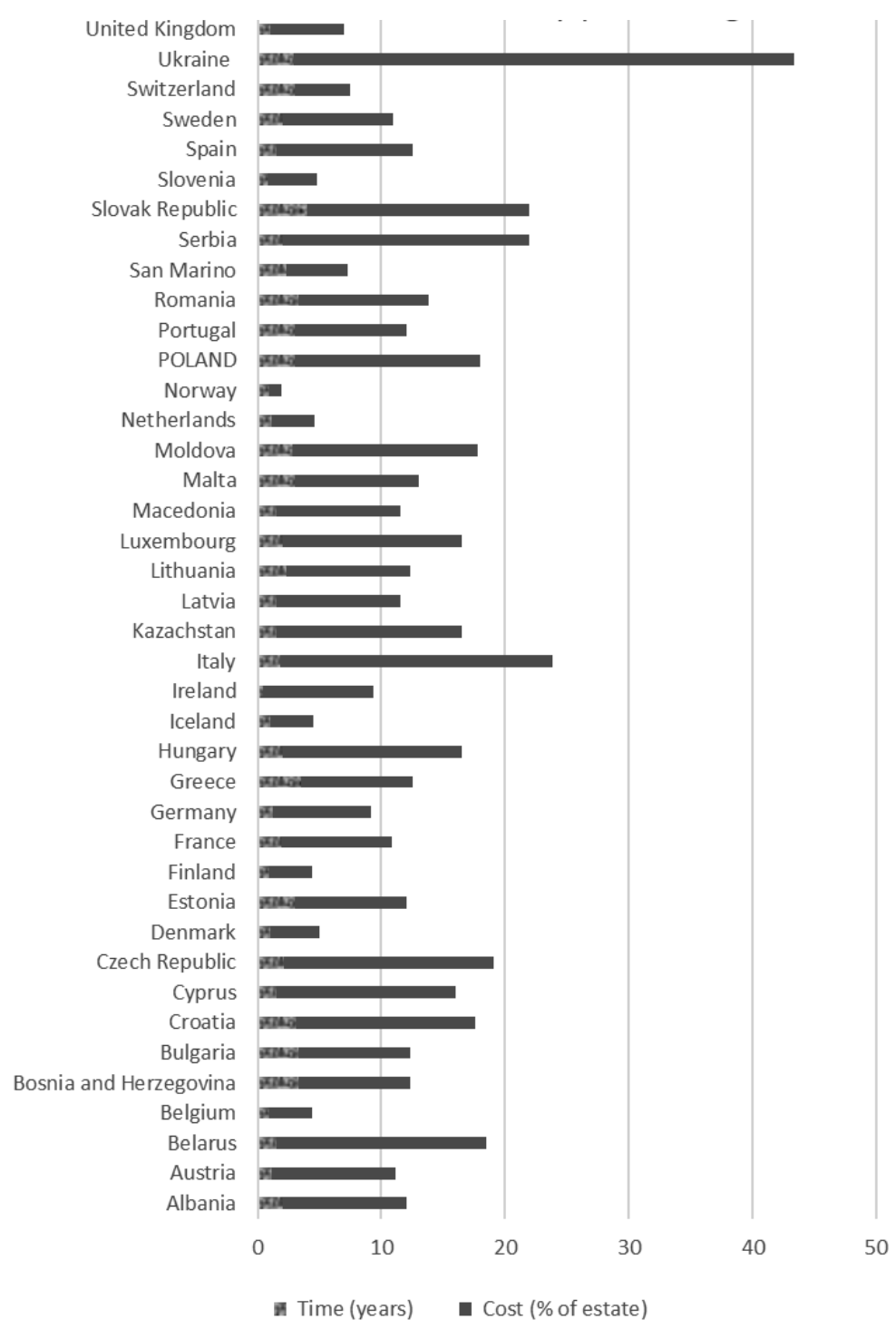

Figure 3. Time and cost of insolvency procedure in European countries

Source: own elaboration on the basis of Doing Business... (2017).

The results of the study indicate that in the case of Poland, while analyzing 2016 to 2010 , no changes occurred. Significant improvement in the field of lack of prevention and streamlining results was recorded in Finland or Greece. 
According to the time and cost of insolvency proceeding (Figure 3) the greatest dispersion is visible in the case of the duration of procedures. The longest insolvency procedure lasts 4 years in Slovak Republic, 3.5 years in Greece 3.5 and 3.3 years in Bosnia and Hercegovina as well as in Bulgaria and Romania. In Poland, the time of insolvency proceeding is 3 years. From the viewpoint of the company functioning on the market, it is a very long period. After this time, there is practically no possibility of continuing operations. Perhaps a change in legal regulations in Poland will shorten this time which seems to be an important element is the mentality of entrepreneurs who do not operate as soon as possible after identifying liquidity problems.

Overloading time generates further problems and increases the risk of insolvency. In Ireland the time is 0.4 of the year, in Finland 0.9 .

As far as the cost is concerned, the results are not so scattered, except for extremely high result in Ukraine: $40.5 \%$ of estate. The lowest cost is borne in Norway $1 \%$, Belgium, as well as Netherlands, Finland, Iceland 3.5\%. In Poland the cost is relatively high $15 \%$.

It was also found, that there are two weak negative (downhill relationships) correlations (Spearman) between high income OECD countries and time (first relationship) or cost (second relationship).

\section{Conclusion}

The crisis of 2007 highlighted the scale of enterprises insolvency. Unfortunately, the scale of this phenomenon does not decrease, but increases. As far as insolvency is inevitable in the case of so-called "Zombie Corporates" which are low-productive and unprofitable, in the case of stable, productive enterprises, this is a destructive phenomenon involving a number of risks and negative effects for the enterprise, stakeholders and the economy.

Therefore, there is a need for continuous improvement of legal systems to facilitate resolving insolvencies. The tools and actions to predict dysfunctions in the financial economy in the early stages are also needed. It is also necessary to strengthen the cooperation between debtors and creditors in order to limit the negative consequences of insolvency. Finally, there is a necessity to change the mindset of managers who will react immediately to any signs of deterioration of their financial condition so as not to lead to insolvency.

\section{References}

Dăianu, D., Pîslaru, D., Voinea, L. (2004). A perspective o insolvency procedures in the Romanian economy. Romania Journal of European Affairs, 4 (4), 37-58. Retrieved from: www.sciencedirect.com (10.02.2018).

Dankiewicz, R. (2009). Wpływ ubezpieczenia kredytu kupieckiego na wyniki działalności przedsiębiorstw. In: K. Jajuga, W. RonkaChmielowiec (eds.), Inwestycje finansowe i ubezpieczenia - tendencje światowe a polski rynek. Wrocław: Wydawnictwo UE Wrocław.

Diamond, D.W., Verrecchia, R.E. (1991). Disclosure, Liquidity, and the Cost of Capital. The Journal of Finance, 46, 1325-1359. DOI: 10.1111/j.1540-6261.1991.tb04620.x.

Doing Business 2018. Reforming to Create Jobs (2017). A World Bank Group Flagship Report. 2018 International Bank for Reconstruction and Development/The World Bank.

Franc-Dąbrowska, J., Porada-Rochoń, M. (2014). Problematyka niewypłacalności małych i średnich przedsiębiorstw w warunkach turbulentnego toczenia. Zeszyty Naukowe PTE, 15, 1-15.

Franc-Dąbrowska, J., Porada-Rochoń, M., Zioło, M., Babczuk, A. (2015). Stabilizowanie finansów podmiotów sektora publicznego i prywatnego w warunkach zaburzeń finansowych. Warszawa: CeDeWu.

Georgescua, I, Baciub, E.C. (2014). The effect of economic crisis on eastern European insolvency. Procedia Economics and Finance, 15, 784-791. Retrieved from: www.sciencedirect.com (12.02.2018). 
Huang, W., Mazouz, K. (2018). Excess cash, trading continuity, and liquidity risk. Journal of Corporate Finance, 48, 275-291. Retrieved from: http://www.sciencedirect.com/science/article/pii/S0929119917306211 (10.02.2018).

Leksykon finansowo-bankowy (1991). Warszawa: Polskie Wydawnictwo Ekonomiczne.

Łodziana, A. (2003). Rachunkowość w jednostkach zagrożonych upadłością. Rachunkowość, 1.

Mączyńska, E. (2017). Wierzytelności - fundamentalna kwestia ekonomiczna i prawna. Biuletyn PTE. Ochrona rzeczywistej Ochrony Praw Wierzycieli, 2 (77).

McGowan, A., Andrews, M.D., Millot, V. (2017). Insolvency Regimes, Technology Diffusion and Productivity Growth: Evidence from Firms in OECD Countries OECD Economics Department Working Papers, No. 1425.

Euler Hermes (2018). Zestawienie procedur windykacyjnych i porównanie ich skuteczności na poszczególnych rynkach w $2018 \mathrm{r}$. Retrieved from: http://www.eulerhermes.pl/euler-hermes-w-polsce/centrum-prasowe/wiadomosci/Pages/180201_Prymus-wułatwianiu-odzyskiwania-należności.aspx (15.02.2018).

Cite this article aS: Porada-Rochoń, M. (2018). Corporate insolvency in Europe. European Journal of Service Management, 1 (25), 221-228. DOI: 10.18276/ejsm.2018.25-27. 